Send your letters to the Editor,

British Dental Journal,

64 Wimpole Street

London

W1G 8YS

E-mailbdj@bda.org

Priority will be given to letters less than 500 words long.

Authors must sign the letter, which

may be edited for reasons of space.

\section{BIO-, ECO- AND NANO-}

Sir, it has been said that nothing has the power of an idea whose time has come. The time has come to speak of ecology, of microbial films in nature ${ }^{1}$ and especially those on teeth that occupy so much of our working lives.

If our research has taught us anything over the past century or so, it is surely that our main professional preoccupations - caries and the chronic inflammatory periodontal diseases - are mostly preventable. If not, then they are at least stoppable and/or controllable. However, as long as we concentrate on treating these diseases in their advanced conditions, prevention will not be at the foremost. One may hope that our patients will not confuse optimum oral health with whitened teeth or veneers. Do they, or we, really believe that the natural colour of human teeth is gloss white?

It seems to me that some researchers are in danger of reinventing the wheel. Is the already established evidence on dental plaque, its formation, structure, biology and role in disease to be rejected because; new researchers will not acknowledge previous research, the 'old' data are not yet available on the Internet, instructors may have overlooked this work, there is an excessive preoccupation with prefixes such as bio, eco-, nano and so forth? It seems that one only has to prefix such a concept with one of the above to be credited with the discovery of an entirely new field of science. There has to be justification for identification to the nano degree.

There may be many biofilms in nature ${ }^{1}$ but in the context of dental plaque only the natural one merits such a classification.
Merely adding 'bio'2 does not sanctify the research, let alone change the facts yielded by previous decades of plaque studies including the long proven relationship with both caries and the chronic periodontal diseases. ${ }^{3,4}$

For how much longer can we expect the public to submit to complex, uncomfortable, time-consuming and increasingly expensive dental treatment when they become aware that most of it could be avoided? It is also time to recognise, with pride, that we are not only surgeons but also physicians: ${ }^{5}$ the title 'doctor' is not honorary. The periodontist's remit is periodontal medicine as well as periodontal surgery ${ }^{6}$ and we may expect at least that their knowledge base should incline practice increasingly towards the former. Similarly, we should guide our patients to think of us as much their doctor as other physicians, since our primary aim is the prevention of disease and tooth loss. We should also seek to achieve this before others begin to ask why we are still treating the preventable in such volume. We can't blame it all on diet and it is hardly good psychology to blame it on the patient.

\section{H. Newman}

London

1. Newman H N. Microbial films in nature. Microbios 1974; 9: 247-257.

2. Newman H N. Biofilms (Letter). The Biologist 2007; 56: 193.

3. Newman $\mathrm{H} \mathrm{N}$. The relation between plaque and dental caries. In Naylor M N (ed). Scientific basis of caries prevention. JR Soc Med 1986; 79 suppl 14: 374 .

4. Newman H N. Plaque and chronic inflammatory periodontal disease - a question of ecology. J Clin Periodontol 1990; 17: 533-541.

5. Newman H N. The dentist as physician. Br Dent J 1998; 185: 374.

6. Newman H N. Parodontalmedizin. Parodontologie 1994; 1: 61-64.

DOI: $10.1038 / b d j .2008 .171$

\section{DIRECT CONTACT}

Sir, I read with great interest an article of a case series of maxillary bone necrosis following use of formaldehyde containing paste by $\mathrm{S}$. Tortorici et al. (BDJ 2007; 203: 511-512).

The authors presented three cases of alveolar bone and soft tissue necrosis due to the use of paraformaldehyde paste during root canal treatment. They stated that necrosis is due to the penetration of formaldehyde from paraformaldehyde paste via dentine into the periodontium. This postulation made by the authors may be true, but I strongly feel that the necrosis of the alveolar bone and soft tissues seen in these three cases is due to the direct contact of the paraformaldehyde paste with the adjacent bone and soft tissue due to the improper coronal temporary restoration of the root canal treated tooth, rather than the penetration of the formaldehyde through dentine into the periodontium.

Usually pulp devitalising agents are placed in a very minute quantity in the pulp chamber when local anaesthesia is not working, and a strong temporary restoration is placed over it. If the temporary restoration fractures or dislodges, there will be direct contact of the pulp devitalising agent with the surrounding hard and soft tissue which may lead to necrosis. I feel this was the reason that led to the necrosis of the alveolar bone and soft tissues in the above mentioned three cases. I too had a similar case in which I had placed pulp devitalising agent (Depulpin-VOVO-Germany) which contains paraformaldehyde on tooth 47 , since local anaesthesia was not working on that particular tooth during pulp extirpation. After three days the patient 
reported to me with necrosis of the buccal mucosa adjacent to tooth 47 . This was due to the fractured temporary restoration on 47 and the direct contact of the pulp devitalising agent (Depulpin) with the adjacent buccal alveolar mucosa. I strongly suggest that whenever a paraformaldehyde or any other caustic pulp devitalising agents are used during root canal therapy, a good coronal double seal should be provided and the patients should be instructed not to bite anything hard over the temporary restoration until the root canal treatment is completed and permanent postendodontic restoration is given.

V. Ballal Manipal

Dr Paulo Difalco responds: Thank you for your letter. According to Cato Censor the purpose of medical treatment is: Primum non nocere (first, do no harm).

The phrase reminds dental professionals that they must consider the possible harm that any intervention might do. It is most often mentioned when debating use of an intervention with an obvious chance of harm but a less certain chance of benefit.

Despite some clinical benefits, paraformaldehyde is not always confined to the pulp, causing tissue necrosis, paraesthesia (as result of trigeminal damage), rare immediate-type allergy (type-I) or anaphylaxis.

In conclusion, the use of paraformaldehyde is obsolete and potentially dangerous. Its use in dental practice is therefore to be strongly discouraged.

DOI: 10.1038/bdj.2008.172

\section{UNUSUAL TIC}

Sir, a 56-year-old gentleman presented with an upper left central incisor that was slightly tender but he had noticed that when he pressed on this tooth the twitch over his left eye that he had suffered from for over five years went away. He had consulted his general practitioner and a hospital specialist on a number of occasions for this twitchy muscle and had had some temporary relief with Botox injections into the muscles above and under the eye which had been repeated on more than five occasions. Over this period there were no dental symptoms, this tooth was not heavily restored and he had attended regularly for routine examinations.

A panoral radiograph from 1998 revealed no pathology surrounding this tooth. On initial examination the tooth showed no vital signs and a periapical radiograph showed apical pathology associated with the tooth. Once the nonvital pulp was removed his twitching eye muscle symptoms cleared up. He has had no further symptoms in four weeks and now the endodontics have been completed we are both waiting to see if his tic returns.

I am interested to know if other readers have come across similar cases; perhaps dental examinations should be carried out before Botox is considered.

M. E. Green Chichester DOI: $10.1038 /$ bdj.2008.173

\section{ASBESTOS DRESSING}

Sir, I read with sadness and interest the obituary of Richard James Bourne (BDJ 2007; 203: 715) who died of mesothelioma. The suggestion was that his only exposure to asbestos had been in University College Hospital's 'tunnels'.

I have no knowledge of the methods of periodontal treatment used at UCH but in 1967/8 at the Royal Dental Hospital of London we applied an 'asbestos resin dressing' to patients' freshly cut gums. The powder mixture was obtained from the clinic stores and mixed with eugenol on a glass slab next to the patient in the dental chair. It was rolled into a sausage shape and applied with bare fingers. I remember a fellow student's comment at the time that asbestos causes cancer.

Two references for the recipe for this gingivectomy dressing can be found in my teachers' textbooks. ${ }^{1,2}$

A. Cook London

1. Wade A B. Basic periodontology, 2nd ed. p 235 Bristol: Wright and Sons, 1965.

2. Manson J D. Periodontics for the dental practitioner. p 77. London: Kimpton, 1966.

DOI: 10.1038/bdj.2008.174

\section{GEORGE CUNNINGHAM}

Sir, the recent article by J. Pearn, Baden-

Powell on teeth: a centenary perspective of a pioneer of preventive dental health (BDJ 2008; 204: 33-36) shows that preventive health advice has a long history and the target group presented a challenge then and now.

In the BDA museum there is a film of the boy scouts, made in 1912 by George Cunningham, showing them in the scout camp in Cambridge whittling at sticks for their camp toothbrushes.

George Cunningham (1852-1919) was also a pioneer in improving oral conditions, especially of children. He used the French film makers the Pathé brothers to make the film setting out preventive health messages using the boy scouts and nursing mothers among others to make dental health education fun. The film was shown at the FDI World Dental Conference in Stockholm in 1912.

This film can be viewed in the BDA museum. As a volunteer at the museum with a special interest in George Cunningham I recommend a visit.

R. Rabin

Croydon

DOI: 10.1038/bdj.2008.175

\section{COPING WITH TREATMENT}

Sir, the article by Craig and Wildsmith on conscious sedation for dentistry (BDJ 2007; 203: 629) provides a useful update, but refers to conscious sedation as a 'technique for dealing with dental phobia'. Possibly the most important use of sedation, particularly in paediatric dentistry, is to help the non-phobic patient to cope with challenging treatment. A full patient assessment prior to treatment should make it possible to anticipate treatment procedures which patients may find it difficult to tolerate. By using sedation in such cases, the subsequent development of dental phobia can be prevented. Once a phobia has developed, subsequent treatment, even with sedation, becomes more difficult, and many such patients may cease dental attendance completely.

A. Crawford Manchester DOI: $10.1038 /$ bdj.2008.176 